\title{
Metallomics
}

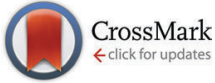

Cite this: Metallomics, 2015 7,805

Received 23rd January 2015, Accepted 2nd March 2015

DOI: $10.1039 / c 5 m t 00024 f$

www.rsc.org/metallomics

\section{Common and metal-specific proteomic responses to cadmium and zinc in the metal tolerant ericoid mycorrhizal fungus Oidiodendron maius $\mathrm{Zn} \dagger$}

\author{
M. Chiapello, E. Martino and S. Perotto*
}

\begin{abstract}
Although adaptive metal tolerance may arise in fungal populations in polluted soils, the mechanisms underlying metal-specific tolerance are poorly understood. Comparative proteomics is a powerful tool to identify variation in protein profiles caused by changing environmental conditions, and was used to investigate protein accumulation in a metal tolerant isolate of the ericoid mycorrhizal fungus Oidiodendron maius exposed to zinc and cadmium. Two-dimensional gel electrophoresis and shotgun proteomics followed by mass spectrometry lead to the identification of common and metal-specific proteins and pathways. Proteins selectively induced by cadmium exposure were molecular chaperons of the Hsp90 family, cytoskeletal proteins and components of the translation machinery. Zinc significantly up-regulated metabolic pathways related to energy production and carbohydrates metabolism, likely mirroring zinc adaptation of this fungal isolate. Common proteins induced by the two metal ions were the antioxidant enzyme Cu/Zn superoxide dismutase and ubiquitin. In mycelia exposed to zinc and cadmium, both proteomic techniques also identified agmatinase, an enzyme involved in polyamine biosynthesis. This novel finding suggests that, like plants, polyamines may have important functions in response to abiotic environmental stress in fungi. Genetic evidence also suggests that the biosynthesis of polyamines via an alternative metabolic pathway may be widespread in fungi.
\end{abstract}

\section{Introduction}

Contamination of soils with metals and metalloids is a major environmental issue because these elements can be potentially very toxic. Due to their persistent nature, toxic metals can lead to the evolution of metal-tolerant organisms that survive in contaminated

Department of Life Sciences and Systems Biology, University of Torino, Viale Mattioli 25, 10125, Turin, Italy. E-mail: marco.chiapello@unito.it, elena.martino@unito.it, silvia.perotto@unito.it; Tel: +390116705987

$\dagger$ Electronic supplementary information (ESI) available: Fig. S1. General pathways of polyamine biosynthesis. Most organisms use arginase to transform L-arginine into putrescine. An alternative pathway uses arginine decarboxylase to convert L-arginine into agmatine, which can be converted either directly or indirectly to putrescine. Putrescine can be then further processed to yield spermidine and spermine. Interaction with the $S$-adenosylmethionine pathway in the synthesis of spermidine and spermine is not shown. Table S1. Identification of 2-DE protein spots. The protein spots excised from 2-DE gels (Fig. 2) were analysed by mass spectrometry and identified by MASCOT on the NCBInr database, as well as on a translated EST database of $O$. maius $\mathrm{Zn}$. Table S2. Complete list of proteins identified by MASCOT in O. maius $\mathrm{Zn}$ samples after shotgun proteomics. The organism of the nearest protein match is indicated, together with the accession number, the protein score and the number of matching peptides. Further description based on conserved protein regions is provided, if available in GenBank. Table S3. GO Terms either over- or underrepresented in the shotgun proteome of the different treatments, as identified by Fisher's exact test. See DOI: $10.1039 / \mathrm{c} 5 \mathrm{mt} 00024 \mathrm{f}$ environments thanks to a range of cell mechanisms. ${ }^{1-5}$ Among soil microbes, mycorrhizal fungi are important because they are ubiquitous symbionts that associate with the roots of most land plants and assist their hosts in nutrient uptake. ${ }^{6}$ In soils with potentially toxic amounts of soluble and insoluble metals, mycorrhizal symbioses can reduce metal toxicity to the host. ${ }^{7-9}$ Adaptive metal tolerance has been reported for both ecto- and endomycorrhizal fungi isolated from polluted soils, ${ }^{10-13}$ although the underlying cellular and molecular mechanisms have been seldom identified. ${ }^{14}$

Similarly to yeast, ${ }^{15}$ metal tolerance in mycorrhizal fungi may derive from a small set of proteins and compounds that can reduce cytoplasmic metal content by chelation, increased efflux or compartmentation of excess metal. ${ }^{16}$ Many of these cell mechanisms confer specific metal tolerance, which is not surprising since each metal has different characteristics and meaning for the living cells. As an example, a metallothionein gene isolated from the ectomycorrhizal fungus Paxillus involutus was found to complement hypersensitivity of yeast mutants to cadmium, but not to zinc. ${ }^{17}$ Similarly, metal transporters that increase metal efflux or vacuole compartmentation usually display metal specificity and are main players in metal tolerance in ericoid ${ }^{9,18}$ as well as in ectomycorrhizal fungi. ${ }^{5,14,19}$

In addition to individual cell components, environmental stress can also induce a more general reconfiguration of metabolic 
pathways that lead to more extensive changes in protein profiles, which can be addressed with proteomics techniques. Global response to heavy metals has been investigated in yeast, ${ }^{20,21}$ but despite recent progress in the proteomics of filamentous fungi, ${ }^{22,23}$ much less is known in these organisms about changes in their protein profiles due to heavy metals. ${ }^{24,25}$ Currently, gel-based two-dimensional electrophoresis (2-DE) has the highest 'protein species' resolution capacity with low-instrumental cost ${ }^{26}$ comprising all possible protein modifications and splice forms. However, the identification process in 2-DE is very insensitive, laborious and depends strongly on protein staining and visualization techniques. Compared to 2-DE, gel-free shotgun proteomics has a much higher capacity in the detection of 'unique' proteins, without differentiating all the different protein forms.

Gel-based and gel-free techniques yield overlapping, but also complementary information, ${ }^{27,28}$ and a combination of these methodologies has been recently applied to investigate the secretome of Trichoderma harzianum on plant biomass substrates. $^{29}$ We have used a similar approach to investigate the proteome of Oidiodendron maius $\mathrm{Zn}$, an ericoid mycorrhizal fungus isolated from a polluted soil, showing adaptive tolerance to zinc and cadmium. ${ }^{13}$ The main aim of this work was to better understand $O$. maius $\mathrm{Zn}$ responses to zinc and cadmium exposure, and in particular to see whether they involve similar cellular and molecular mechanisms, or whether metal-specific responses are induced. O. maius $\mathrm{Zn}$ is emerging as a model organism for mycorrhizal fungi. Stable genetic transformation and gene disruption by homologous recombination were obtained for the first time in this fungus, ${ }^{30,31}$ and $O$. maius $\mathrm{Zn}$ genome and transcriptome have been recently sequenced in the framework of a JGI CSP programme. ${ }^{32}$ This genetic information allowed us to further investigate the sequences identified by proteomics.

\section{Results and discussion}

\section{Fungal growth in the presence of $\mathrm{Zn}$ and $\mathrm{Cd}$}

Growth of $O$. maius $\mathrm{Zn}$ in liquid medium amended with either $0.05 \mathrm{mM} \mathrm{CdSO}_{4}$ or $10 \mathrm{mM} \mathrm{ZnSO}_{4}$ is shown in Fig. 1. As found in previous experiments, ${ }^{13}$ fungal mycelium exposed to zinc produced significantly more biomass than control mycelium after 30 days of liquid culture, whereas cadmium reduced mycelial growth significantly. To investigate long-term response of $O$. maius $\mathrm{Zn}$ to zinc and cadmium, proteins were extracted from fungal mycelia 30 days after the medium was amended with the metal ions.

\section{Analyses of protein profiles through 2-DE and shotgun proteomics}

2-DE analysis. After 2-DE separation, protein spots visualized on the gels ranged $16-120 \mathrm{kDa}$ in molecular weight and 4-7 in pI. Fig. 2 shows one representative gel for each condition investigated. Very good similarity index $(>80 \%)$ and correlation coefficient $(>0.8)$ were calculated for both technical and biological replicates of all protein samples. Analysis with the PDQuest Software (Bio-Rad) system revealed, from each match-set of protein profiles, 270 detectable spots for the

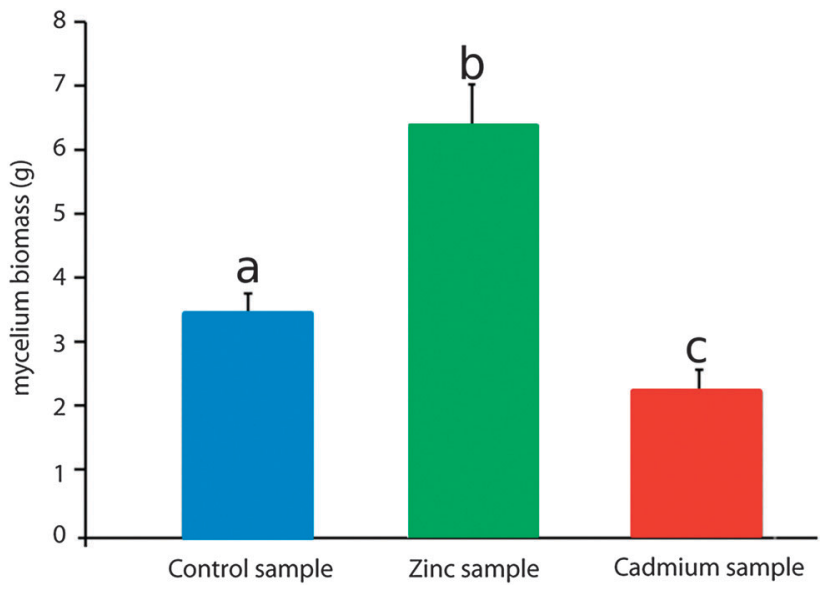

Fig. 1 Effect of zinc and cadmium sulphates on the growth of Oidiodendron maius $\mathrm{Zn}$. Total biomass is reported as grams of fungal mycelium (fresh weight) after 30 days of culture in metal-amended and unamended medium. Bars represent the mean $\pm \mathrm{SE}, n=5$. Statistically significant differences $(P \leq 0.05)$ between treatments are indicated by different letters above the bars.

control samples, 310 for the cadmium treatment and 251 for the zinc treatment (Fig. 3A).

Compared with the other two samples, mycelia treated with zinc consistently yielded a smaller number of protein spots on the 2-DE gels, even though equal loading was applied to the first dimension, as evaluated by the Bradford method. Since protein spots were quantitatively stained by the SYPRO-Ruby fluorescent dye, the Wilcoxon test was used to verify the total amount of protein in the 2-DE gels after separation of the zinc treated samples. The $p$-values obtained, when compared with control sample (0.244) and with cadmium sample (0.083), indicate that differences in the total amount of proteins visualized on the gels were not statistically significant. Thus, proteins were not lost during the processing of zinc samples, and the smaller number of protein spots observed was likely due to high abundance of some proteins.

The Venn diagram (Fig. 3A) shows the number of protein spots only found in a single treatment, or shared between different samples. Although the growth of O. maius $\mathrm{Zn}$ was not inhibited (and even increased) by the addition of zinc at $10 \mathrm{mM}$ concentration, the protein profiles of the control and the zinc treated samples showed a low similarity index (31.23\%) and correlation coefficient (0.368). Zinc and cadmium samples also showed low similarity index $(31.75 \%)$ and correlation coefficient $(0.446)$, whereas a higher similarity index $(47.81 \%)$ and correlation coefficient (0.605) were found between control and cadmium samples.

Quantitative analysis after SYPRO-Ruby gel staining indicated that many proteins shared between treatments were differentially regulated. Scatter plots of staining intensities of shared protein spots after pairwise comparison of the different growth conditions is shown in Fig. 4. When control and cadmium treated samples were compared (Fig. 4A), about $60 \%$ of protein spots were not regulated, about $18 \%$ were up-regulated and about $16 \%$ were down-regulated in the cadmium sample. Together with the high correlation coefficient (0.61), these data indicate that most proteins shared between control and cadmium treated samples 

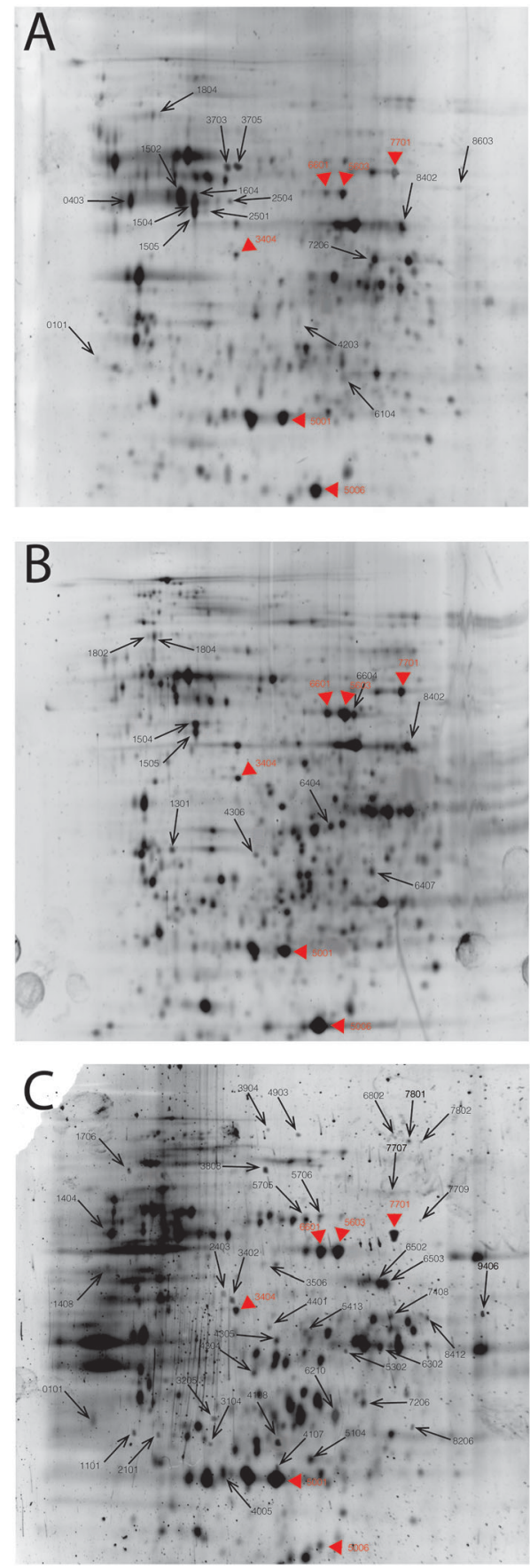

Fig. 2 Two-dimensional electrophoresis profiles of SYPRO-Ruby stained fungal proteins from $\mathrm{O}$. maius $\mathrm{Zn}$. (A) Control mycelium; (B) cadmium treated mycelium; (C) zinc treated mycelium. The protein spots excised for mass spectrometry from each gel are indicated by an arrow. Red arrowheads indicate shared protein spots that were excised by 2-DE gels of all treatments (see Table S1, ESI $\dagger$ ).

were not differentially accumulated. Pairwise comparison of control and zinc treated samples showed a wide spot dispersion (Fig. 4B). About $42 \%$ of protein spots were not regulated, $21 \%$ were up-regulated and $30 \%$ were down-regulated in the zinc sample.

These data, together with the low correlation coefficient (0.37), indicate that proteins shared between control and zinc
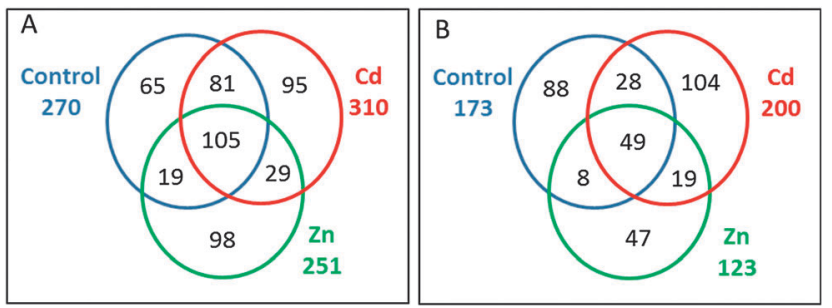

Fig. 3 Venn diagrams reporting the number of proteins either found in a single treatment or shared among the different conditions tested: control sample, zinc treated $(\mathrm{Zn})$ and cadmium treated $(\mathrm{Cd})$ samples. Total protein numbers for each sample are also indicated. (A) Number of proteins spots visualised on 2-DE gels and analysed by the PDQuest software; (B) number of proteins identified by shotgun proteomics and mass spectrometry.

treated sample highly differed in their accumulation. An intermediate situation, with a correlation coefficient of 0.45 , was found when cadmium and zinc treated samples were compared (Fig. 4C). In this case, about $46 \%$ of proteins showed the same expression, while $16 \%$ were up-regulated in the zinc sample and $31 \%$ of proteins were up-regulated in the cadmium sample.

Spots found in a single treatment as well as the spots shared among treatments were excised from the 2-DE gels and processed for tandem mass spectrometry for protein identification, followed by MASCOT analysis. Out of 92 excised spots, 65 yielded peptide sequences with a positive match in the database with $p$-value $<0.05$, and 33 of them corresponded to hypothetical proteins (Table S1, ESI $\dagger$ ). To confirm and improve protein identification, the peptide sequences obtained by tandem mass spectrometry were used as queries in Blast searches against a translated EST library of $O$. maius $\mathrm{Zn}$. The putative function of the EST matching sequences, based on Pfam conserved regions, is reported in Table S1 (ESI + ). With this procedure, all protein identifications by MASCOT were confirmed, and 30 out of the 33 hypothetical proteins were further identified (Table S1, ESI $\dagger$ ). Table S1 (ESI $\dagger$ ) also shows abundance of the identified proteins in the different treatments, as assessed by quantitative analysis after SYPRO-Ruby gel staining.

Shotgun proteomics. Proteins that could be identified by shotgun proteomics with at least two peptides and $p$-value $<0.05$ are listed in Table S2 (ESI $\dagger$ ). With this approach, we could identify 173 proteins in the control mycelium, 200 in the mycelia exposed to cadmium and 123 in the mycelium exposed to zinc (Fig. 3B), with an average number of 3.8 peptides/ protein.

The total number of proteins identified by shotgun proteomics confirmed that cadmium induced the highest number of diverse proteins in O. maius $\mathrm{Zn}$, and that the total number of proteins extracted from the mycelium exposed to zinc was comparably lower than the other samples. The results of shotgun proteomics also confirmed that fungi grown in control and cadmium media showed the most similar protein profiles, with 28 identical proteins (Fig. 3B), whereas control and zinc media shared only 8 proteins.

Table 1 summarizes the functional classification of the proteins identified using the KEGG database. 
(A) Control vs Cadmium
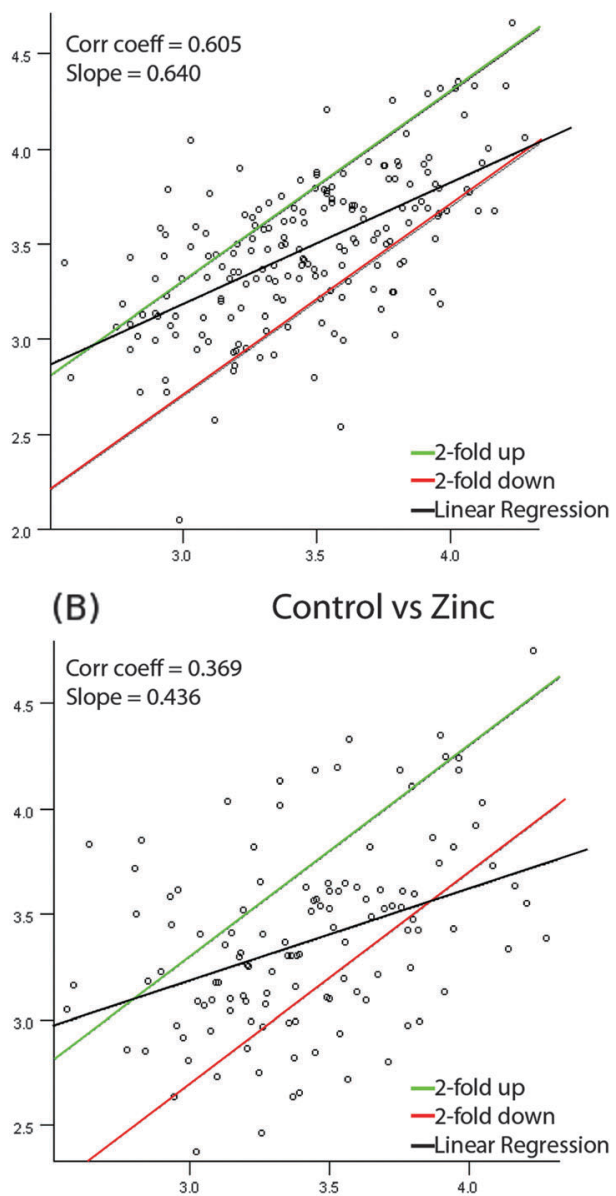

(C) Cadmium vs Zinc

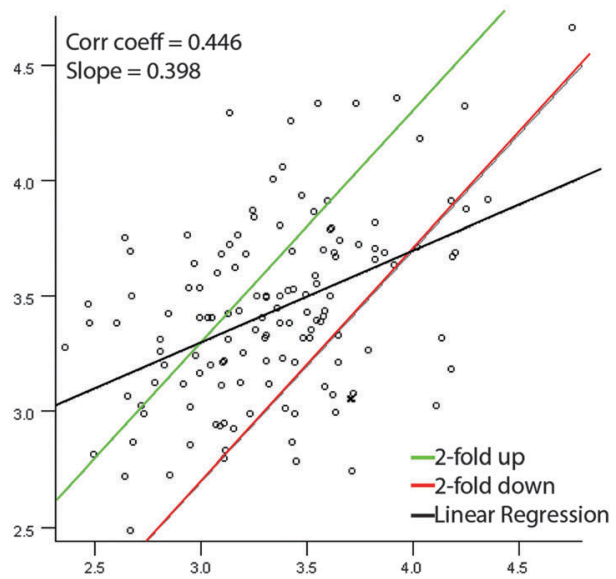

Fig. 4 Scatter plots showing the intensity of protein spots visualised on 2-DE gels and shared between samples exposed to different treatments. A pairwise comparison is shown for the three different conditions. The first comparison term is reported on the $y$ ass, while the second comparison term is reported on the $x$ ass. (A) Variation of control versus cadmium treated sample; (B) variation of control versus zinc treated sample: (C) variation of cadmium treated versus zinc treated sample. We considered proteins with a higher than two-folds increase in intensity (above upper lines) as being up-regulated, and lower than two-folds (under lower lines) as being down-regulated. Expression of spots between the two lines was considered unchanged. Intensity of the individual spots was normalized as described by Arora et al. (2005). ${ }^{33}$ The regression lines are also shown.
Table 1 KEGG pathways detected by shotgun proteomics in the O. maius Zn samples using the KAAS software and fungi as reference organisms. Four main biological processes were subdivided into functional classes

\begin{tabular}{llll}
\hline & $\begin{array}{l}\text { Control } \\
(\%)\end{array}$ & $\begin{array}{l}\text { Cadmium } \\
(\%)\end{array}$ & $\begin{array}{l}\text { Zinc } \\
(\%)\end{array}$ \\
\hline Metabolism & 69.27 & 49.89 & 80.23 \\
Carbohydrate metabolism & 29.47 & 27.46 & 44.70 \\
$\begin{array}{l}\text { Energy metabolism } \\
\text { Lipid metabolism }\end{array}$ & 16.37 & 12.59 & 24.64 \\
Nucleotide metabolism & 3.02 & 0.46 & 0.00 \\
Amino acid metabolism & 1.01 & 0.92 & 0.00 \\
Metabolism of other amino acids & 15.11 & 7.09 & 9.74 \\
Glycan biosynthesis and metabolism & 1.51 & 0.46 & 1.15 \\
Metabolism of terpenoids and & 0.00 & 0.00 & 0.00 \\
polyketides & & 0.46 & 0.00 \\
Biosynthesis of other secondary & 0.25 & 0.23 & 0.00 \\
metabolites & & & \\
Xenobiotics biodegradation and & 1.26 & 0.23 & 0.00 \\
metabolism & & & \\
& & & \\
Genetic information processing & 17.13 & 24.03 & 9.17 \\
Transcription & 4.28 & 2.06 & 0.29 \\
Translation & 2.52 & 6.86 & 1.15 \\
Folding, sorting and degradation & 10.33 & 15.10 & 7.74 \\
& & & \\
Environmental information processing & 7.81 & 12.81 & 9.74 \\
Signal transduction & 7.81 & 12.81 & 9.74 \\
Cellular processes & & & \\
Transport and catabolism & 5.79 & 13.27 & 0.86 \\
Cell motility & 5.29 & 5.49 & 0.86 \\
Cell growth and death & 0.00 & 1.37 & 0.00 \\
Cell communication & 0.50 & 0.92 & 0.00 \\
& 0.00 & 5.49 & 0.00 \\
& & &
\end{tabular}

Metal-specific responses of $O$. maius $\mathrm{Zn}$ to zinc and cadmium exposure

Both proteomic approaches revealed very little protein overlaps between mycelia exposed to cadmium and to zinc. Although we cannot exclude that some of the responses identified for one metal may be also up-regulated in the other treatment, due to the small size of the protein datasets, the KEGG and Fisher's exact test of GO terms clearly point to a differential induction of some metabolic pathways. Shotgun proteomics revealed that, when compared to the other samples, zinc treated mycelia featured the highest percentage of proteins involved in metabolism, in particular carbohydrates and energy metabolism (Table S2, ESI $\dagger$ ). An enrichment analysis using the Fisher's exact test (Table S3, ESI $\dagger$ ) further confirmed a significant over-representation of GO terms related to carbohydrates and energy metabolism in the zinc sample. 2-DE analysis indicated a similar result because zinc treatment, in addition to enzymes involved in glycolysis, specifically induced proteins corresponding to aconitase (Table S1, ESI $\dagger$ ), an enzyme that catalyzes the conversion of citrate to isocitrate in the tricarboxylic acid cycle.

It was quite surprising to find that the high zinc concentration $(10 \mathrm{mM})$ used in the experiments up-regulated carbohydrates and energy metabolism significantly more than the control medium in O. maius Zn. Up-regulation of these metabolic pathways would however explain the higher fungal biomass produced on zinc amended medium. As the name indicates, this fungus was originally derived from a soil where zinc was the most abundant heavy metal, ${ }^{34}$ and its behaviour in vitro may simply mirror an 
adaptation to the original soil pollution. Similarly, highly Zn-tolerant isolates of Suillus luteus grew poorly at low zinc concentrations, in contrast with less tolerant isolates of the same species. ${ }^{11}$

In addition to a metabolic role, enzymes responsible of organic acids biosynthesis, such as those involved in the tricarboxylic acid cycle, may also play a role in metal tolerance because organic acids represent a known metal tolerance mechanism in mycorrhizal fungi. ${ }^{16}$

In response to oxidative stress, fungi can redirect their metabolic flux from glycolysis to the pentose phosphate pathway, in order to increase the production of reducing power. ${ }^{35}$ It is possible that this metabolic re-routing specifically occurred in the mycelium exposed to cadmium. GO terms related to glycolysis (as biological function) and glyceraldehyde-3-phosphate dehydrogenase activity (as molecular function) were under-represented after cadmium exposure (Table S3, ESI $\dagger$ ), whereas transketolase, a key enzyme in the pentose phosphate pathway, was uniquely found in this sample by shotgun proteomic (Table S2, ESI $\dagger$ ).

Many proteins identified in the 2-DE experiments were also detected in the shotgun proteomic experiments, like enzymes of the glycolytic pathway and molecular chaperones. Heavy metal ions are potent inhibitors of protein folding, as they inhibit very efficiently the spontaneous and chaperone-assisted refolding of denatured proteins. ${ }^{36}$ However, whereas members of the Hsp70 family were found in all samples, molecular chaperones of the Hsp90 family were almost uniquely found after exposure to cadmium. Hsp90 is a conserved molecular chaperone identified in fungi, animals and plants and suggested to be an essential component of the protective response to several abiotic stresses, including heavy metals. ${ }^{37-39}$ In eukaryotes, Hsp90s act on a specific set of client proteins and help to regulate, under normal conditions and environmental challenges, the activities of a number of transcription factors and kinases involved in signal transduction, cell cycle control and development. ${ }^{37,40}$ Experimental observations indicate that the fungal Hsp90 interactome displays considerable environmental plasticity. ${ }^{37}$ Hsp90s have been also found to interact, either directly or indirectly, with the cytoskeletal framework. ${ }^{41,42}$ The specific role of Hsp90s in O. maius $\mathrm{Zn}$ mycelium exposed to cadmium remains to be established, but it is intriguing that both actin and tubulin were specifically identified in the cadmium treated sample using shotgun proteomics (Table S2, $\mathrm{ESI} \dagger$ ). Taken together, these results may suggest a fungal response related to cell division and hyphal growth.

Our proteomic data confirm the general observation that different heavy metals may induce metal-dependent responses in fungi. ${ }^{43}$ In particular, 2-DE analysis of proteins secreted by the plant pathogen Botrytis cinerea in response to different metals indicated that cadmium induces a secretome signature significantly different from those induced by zinc, copper or nickel. ${ }^{25}$ A genome-wide investigation in yeast also reported metalspecific responses and detoxification pathways following acute exposure to cadmium and zinc, the first mainly inducing sulphur compound metabolism and the latter iron ion homeostasis. ${ }^{44}$ Proteins involved in these two pathways were not found in O. maius $\mathrm{Zn}$, which may be either explained by the low protein coverage or by the fact that metal exposure was much longer in our experiments (30 days). Unlike yeast, O. maius $\mathrm{Zn}$ is also a highly metal tolerant organism, and cell responses likely differ.

\section{Common responses of $O$. maius $\mathrm{Zn}$ to zinc and cadmium exposure}

Mycelia exposed to cadmium and zinc shared a limited number of proteins (Fig. 3), and some of these proteins are well known in most organisms to take part in the general response to stress, including heavy metals. For example, two $\mathrm{Cu} / \mathrm{Zn}$ superoxide dismutases were identified by shotgun proteomics in mycelia exposed to both metals, but not in the control sample (Table S2, ESI $\dagger$ ). $\mathrm{Cu} / \mathrm{Zn}$ superoxide dismutase ( $\mathrm{Cu} / \mathrm{Zn}$ SOD) plays a major role in the cell defence against toxic reduced oxygen species. Oxygen radicals are generated as by-products of many biological oxidations, but their production can be further increased by heavy metals. ${ }^{45}$ One of the two $\mathrm{Cu} / \mathrm{Zn}$ SODs identified (Table S2, ESI $\dagger$ ) is coded by a gene previously investigated in O. maius $\mathrm{Zn} .^{31,46}$ Its genetic disruption demonstrated the role of $\mathrm{Cu} / \mathrm{Zn}$ SOD in zinc and cadmium tolerance, as growth of $O$. maius $\mathrm{Zn}$ knock-out mutants was significantly impaired on media containing these two metals. ${ }^{31}$

Ubiquitin, a small and highly-conserved regulatory protein found in eukaryotes, was also identified by shotgun proteomics after exposure to both zinc and cadmium (Table S2, ESI $\dagger$ ). Covalent attachment of ubiquitin to lysine residues of proteins is a post-translational modification that was originally described as a destruction tag that directs misfolded or disused proteins to the proteasome, where the ubiquitin is recycled and the protein is degraded. ${ }^{47}$ Some components of the proteasome were identified by 2-DE in the mycelium exposed to both cadmium and zinc (Table S1, ESI $\dagger$ ). This may indicate a more intense proteolytic activity to eliminate misfolded proteins. Several proteins involved in ubiquitin-dependent proteolysis were also identified by Muller et al. $(2007)^{48}$ when comparing the gene expression profiles of a Zn-tolerant and a Zn-sensitive Suillus luteus isolate exposed to increased external zinc concentrations. In O. maius $\mathrm{Zn}$ exposed to cadmium, over-representation of GO terms related to the translational machinery (Table S3, ESI $\dagger$ ) may mirror this process, as proteolysis must be balanced by protein biosynthesis in homeostatic conditions. A strong up-regulation of proteins involved in the translation machinery was reported also for the white rot fungus Phanerochaete chrysosporium in response to cadmium. ${ }^{24}$

The enzyme acetohydroxy acid isomeroreductase, a ketolacid reductoisomerase, was found in the cadmium and in the zinc treated samples (Table S1, ESI $\dagger$ ). Although its role in stress response is unclear, this enzyme is involved in the biosynthesis of the hydrophobic amino acids valine, leucine and isoleucine, a metabolic pathway also induced by heat stress in the plant Populus euphratica. ${ }^{49}$

Another protein induced both by zinc and cadmium exposure, albeit detected in the two samples by different techniques, is ATP synthase. Up-regulation of ATP synthase activity in an aluminium resistant wheat cultivar has been reported by Hamilton et al. $(2001)^{50}$ and it has been considered as a possible adaptive response involved in $\mathrm{Al}$ resistance. A proteomic analysis of poplar leaves exposed to cadmium revealed that mitochondrial 
respiration and ATP synthase activity were up-regulated, providing energy in cadmium-exposed plants. ${ }^{51}$

An interesting protein identified by shotgun proteomics and induced in $O$. maius $\mathrm{Zn}$ by both cadmium and zinc was the enzyme agmatinase (Table S2, ESI $\dagger$ ), a key enzyme in the biosynthesis of polyamines. ${ }^{52}$ Up-regulation of this enzyme in the zinc and cadmium treated samples was also revealed by 2 -DE, where protein spot 4108 corresponded to agmatinase 1 (MGG_10533) of Magnaporthe grisea (Table S1, ESI $\dagger$ ). When the peptides identified by 2-DE or shotgun proteomic were blasted on a translated EST database of $O$. maius $\mathrm{Zn}$, they matched the same protein. Agmatinase belongs to the ureohydrolase superfamily (Pfam PF00491), which also includes arginase, formiminoglutamase, guanidinobutyrase, proclavaminate amidinohydrolase and related

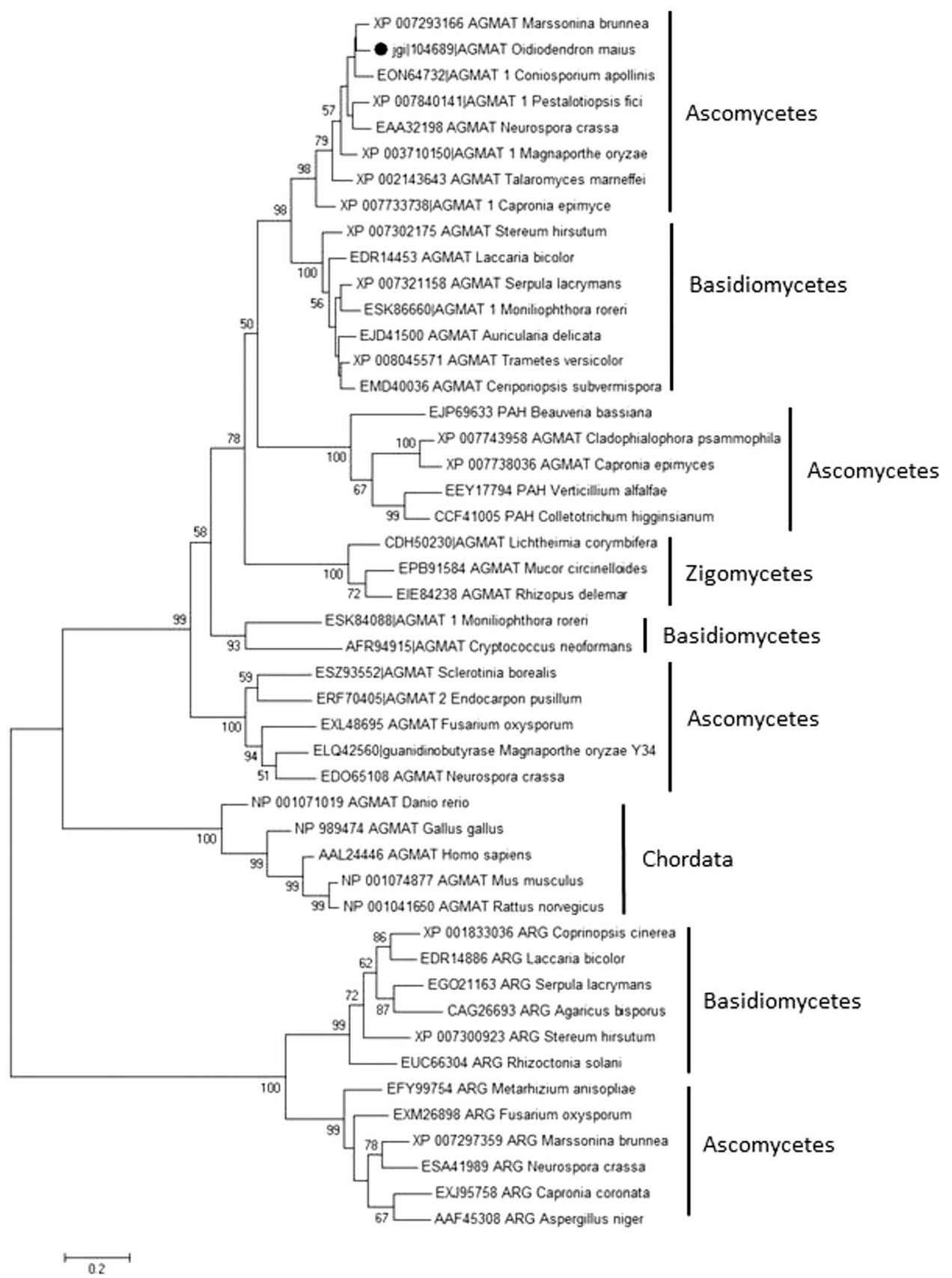

Fig. 5 Phylogenetic tree of the ureohydrolase superfamily showing relationships among protein sequences identified in fungi. Representative protein sequences from different fungal phyla submitted to GenBank as arginase (ARG), agmatinase (AGMAT), proclavaminate amidinohydrolase (PAH) or guanidinobutyrase were aligned with Muscle together with some agmatinase sequences from Chordata. Fungal sequences corresponding to formiminoglutamase were not found. The unrooted tree was constructed using Maximum Likelihood, and shows that the $O$. maius $Z n$ protein identified in the proteomic experiments $(\bullet)$ groups together with agmatinases from other ascomycetes in a well-supported cluster. Similar proteins retrieved from the O. maius Zn genome at JGl clustered in separate groups. Numbers indicate bootstrap values, and are indicated only when $\geq 50 \%$. 
proteins. In particular, all enzymes listed above, except arginase, feature a conserved domain (cd09990 on NCBI), which places them in the agmatinase-like family. As these enzymes share some structural similarities, we built a phylogenetic tree to clarify the relationship of the $O$. maius $\mathrm{Zn}$ protein with other members of this superfamily (Fig. 5).

The complete $O$. maius $\mathrm{Zn}$ protein sequence, available on the JGI Mycocosm portal, ${ }^{53}$ was aligned with representative fungal sequences submitted to GenBank, as well as with animal sequences. In the Maximum Likehood (ML) tree in Fig. 5, fungal agmatinases grouped in a well-supported clade (99\% bootstrap support), distinct from animal agmatinases. Within the fungal agmatinase-like family clade, sequences from asco- basidio- and zygomycetes grouped in separate clusters, mirroring fungal taxonomy. As expected, arginase sequences from asco- and basidiomycetes grouped in a separate, well-supported cluster (100\% bootstrap support). The O. maius Zn protein (ID 104689) clustered with ascomycetes sequences submitted to GenBank as agmatinase (or agmatinase 1). The ML tree showed, within the large agmatinase-like family clade, two other well-supported clusters of ascomycetes sequences (Fig. 5). In these clusters, however, sequences submitted to GenBank as agmatinase (or putative agmatinase) grouped together with sequences submitted as proclavaminate amidinohydrolase (100\% bootstrap support) or as guanidinobutyrase (100\% bootstrap support), respectively, thus suggesting that they may represent other enzymes of the agmatinase-like family.

Identification of agmatinase in the $O$. maius $\mathrm{Zn}$ proteome in response to metals is very intriguing for different reasons. Polyamines are positively charged small molecules found in prokaryotic and eukaryotic cells; putrescine and spermidine, in particular, are believed to occur in all living cells and to be implicated in many fundamental cellular processes. ${ }^{54,55}$ In plants, polyamine accumulation appears to be a universal response to stress, including toxic heavy metal concentrations. ${ }^{56-61}$ How polyamines may function in protecting cells from abiotic stresses is still unclear, but direct and indirect mechanisms may be involved, as discussed by Alcázar et al. $(2010)^{57}$ and Minocha et al. (2014). ${ }^{60}$

In fungi, polyamines are essential to support growth and to regulate a wide variety of biological phenomena, ${ }^{62,63}$ but little is known about their possible role in stress tolerance. ${ }^{64}$ To our knowledge, polyamine accumulation in response to heavy metals was only investigated in the ectomycorrhizal fungus Paxillus involutus, where lead and zinc exposure specifically increased cellular concentrations of some polyamines. ${ }^{65,66}$ Although we have not measured polyamines content in $O$. maius $\mathrm{Zn}$, our results suggest that the biosynthetic pathway leading to the formation of these compounds is induced by both zinc and cadmium. Agmatinases are metalloenzymes, and a metal ion binding molecular function (GO: 0046872) was identified by Gene Ontology in the $O$. maius $\mathrm{Zn}$ protein. Thus, this protein may contribute to metal tolerance not only through its enzymatic activity, but also because of its metal binding capability. Similarly, the protective effect of $\mathrm{Cu} / \mathrm{Zn}$ SOD against zinc toxicity was suggested to involve both metal-binding and enzymatic activities. ${ }^{67}$
Identification of agmatinase in $O$. maius $\mathrm{Zn}$ raises intriguing questions on the polyamines biosynthetic pathway in fungi (Fig. S1, ESI $\dagger$ ). Most organisms produce polyamines from L-arginine exclusively via arginase and ornithine decarboxylase (ODC). According to classical work and recent literature, fungi seem to feature uniquely this pathway for polyamine biosynthesis, ${ }^{62,68-70}$ also because strains of Saccharomyces cerevisiae, Neurospora crassa and Aspergillus nidulans carrying mutations in the ODC gene were putrescine auxotrophic. ${ }^{71}$

Many bacteria, plants and protozoa can also use an alternative pathway to synthesize putrescine from L-arginine (Fig. S1, ESI $\dagger$ ) via arginine decarboxylase (ADC) and agmatinase. ${ }^{72}$ The same pathway was discovered in mammals in the mid-90, ${ }^{73}$ but it was considered to be unlikely in fungi because ADC activity could not be detected in many species. ${ }^{74}$

Significant levels of ADC activity have been later reported for fungi belonging to different phyla, ${ }^{75-79}$ and support earlier feeding experiments with radiolabeled ${ }^{14} \mathrm{C}$-L-arginine showing the formation of radioactive agmatine and putrescine in the basidiomycete Panus tigrinus. ${ }^{80}$ The putrescine biosynthetic pathway in fungi requires further investigations, and the extensive genome sequencing projects will be an important source of information to better understand the genetic potential of fungi in the different biochemical pathways, and the role of polyamines in the fungal response to environmental stress.

\section{Conclusions}

Proteomic analysis of $O$. maius $\mathrm{Zn}$ response to cadmium and zinc by 2-DE gels and shotgun proteomics revealed that, like in other organisms, these two heavy metals induce metal-specific as well as common responses in this ericoid mycorrhizal fungus. Some of the proteins identified in O. maius $\mathrm{Zn}$, like the enzyme agmatinase, represent novel findings in relation to heavy metal response in fungi, and deserve further investigations.

\section{Experimental}

\section{Fungal isolates}

The metal tolerant $O$. maius strain $\mathrm{Zn}$ is deposited in the MUT collection at the University of Turin (MUT 1831). This strain was isolated in the Niepolomice Forest (Poland) from mycorrhizal roots of Vaccinium myrtillus growing in experimental plots treated with industrial dusts derived from electro-filters and containing high concentrations of zinc, cadmium and aluminium. The characteristics of the site and the identification of this fungal isolate are described in Martino et al. (2000). ${ }^{34}$

\section{Growth conditions}

Fungal cultures were grown under shaking conditions at $120 \mathrm{rpm}$ in conical flasks at $25{ }^{\circ} \mathrm{C}$ in Czapek-pectin liquid medium containing the following reagents, all purchased from SIGMA: $\mathrm{NaNO}_{3} 3 \mathrm{~g} \mathrm{~L}{ }^{-1}, \mathrm{~K}_{2} \mathrm{HPO}_{4} \cdot 3 \mathrm{H}_{2} \mathrm{O} 1.31 \mathrm{~g} \mathrm{~L}{ }^{-1}, \mathrm{MgSO}_{4} \cdot 7 \mathrm{H}_{2} \mathrm{O}$ $0.5 \mathrm{~g} \mathrm{~L}^{-1}, \mathrm{FeSO}_{4} \cdot 7 \mathrm{H}_{2} \mathrm{O} 0.01 \mathrm{~g} \mathrm{~L}^{-1}, \mathrm{KCl} 0.5 \mathrm{~g} \mathrm{~L}^{-1}$, pectin $8 \mathrm{~g} \mathrm{~L}^{-1}$, $20 \mathrm{mM}$ MES (2-[N-morpholino]ethanesulphonic acid), pH 5.5. 
Zinc was added as $\mathrm{ZnSO}_{4} \cdot 7 \mathrm{H}_{2} \mathrm{O}$ (Merck, pur. 98\%) at a final concentration of $10 \mathrm{mM}$, while cadmium was added as $3 \mathrm{CdSO}_{4}$. $8 \mathrm{H}_{2} \mathrm{O}$ (SIGMA, pur. 98\%) at a final concentration of $0.05 \mathrm{mM}$. These two metals were chosen as they were among the most abundant in the site where the fungus was isolated. Their concentrations were chosen on the basis of previous growth experiments on O. maius $\mathrm{Zn} .^{13}$ For each condition tested, 5 biological replicates were analysed.

\section{Protein extraction and 2-DE separation}

The O. maius $\mathrm{Zn}$ mycelium was recovered by filtration and homogenised in liquid nitrogen. Intracellular proteins were extracted in cold extraction buffer as described by BestelCorre et al. (2002). ${ }^{81}$ All reagents were purchased from Sigma. The crude homogenate was centrifuged at $4{ }^{\circ} \mathrm{C}(10000 \mathrm{~g}$ for $30 \mathrm{~min}$ ). The supernatant was carefully removed, centrifuged again and dialysed overnight against $\mathrm{Na}_{2} \mathrm{PO}_{4} 20 \mathrm{mM}$, EDTA $0.1 \mathrm{mM}$. Phenol saturated in $100 \mathrm{mM}$ TrisHCl, $\mathrm{pH} 8$ was added to the sample $(1: 1 \mathrm{v} / \mathrm{v})$. After mixing for $30 \mathrm{~min}$ at $4{ }^{\circ} \mathrm{C}$, the phenolic phase was separated by centrifugation. Proteins were precipitated overnight at $-20{ }^{\circ} \mathrm{C}$ with 5 volumes of $100 \%$ methanol containing $0.1 \mathrm{M}$ ammonium acetate. The pellet was recovered by centrifugation, rinsed with cold $100 \%$ methanol and $100 \%$ acetone, dried, resuspended in $800 \mu \mathrm{L}$ of solubilization buffer containing $9 \mathrm{M}$ urea, $2 \%$ Triton X-100 and centrifuged for $30 \mathrm{~min}$ at $25000 \mathrm{rpm}, 20{ }^{\circ} \mathrm{C}$. Protein content was determined by the method of Bradford (1976), ${ }^{82}$ using bovine serum albumin (BSA, SIGMA) as a standard. Isoelectric focusing (IEF) was performed on immobilized $\mathrm{pH}$ gradient (IPG) strips in a Protean IEF Cell (Bio-Rad). Samples of $400 \mu \mathrm{g}$ of proteins mixed with $2 \%(\mathrm{v} / \mathrm{v})$ IPG buffer and $0.1 \mathrm{M}$ DTT were loaded on each IPG strip and focused at $15{ }^{\circ} \mathrm{C}$ for $70000 \mathrm{~V} \mathrm{~h}$ after 16 hours of rehydration. IPG strips were then either stored at $-80{ }^{\circ} \mathrm{C}$ or sequentially washed with equilibration buffers 1 (urea $6 \mathrm{M}$; Tris-HCl $0.375 \mathrm{M}$, pH 8.8; glycerol 20\%; SDS 2\%; DTT $130 \mathrm{mM}$ ) and 2 (urea $6 \mathrm{M}$; Tris- $\mathrm{HCl} 0.375 \mathrm{M}, \mathrm{pH} 8.8$; glycerol $20 \%$; SDS $2 \%$; iodoacetamide $35 \mathrm{mM}$ ) for 10 minutes each, with gentle agitation. For second dimension electrophoresis, the equilibrated IPG strips were rinsed with Tris-Glycine-SDS buffer (25 mM Tris base, $192 \mathrm{mM}$ glycine, 0.1\% SDS) prior to being loaded onto $10 \%$ SDS-polyacrylamide gels $(0.1 \mathrm{~cm} \times 19 \mathrm{~cm} \times$ $23 \mathrm{~cm})$ prepared in electrophoresis buffer $(0.375 \mathrm{M}$ Tris $\mathrm{pH} 8.8$, $0.1 \%$ SDS) and polymerized overnight before 2-DE separation. Proteins were separated for 5 hours at $10{ }^{\circ} \mathrm{C}$ under constant current (24 mA for each gel). Following electrophoresis, gels were kept overnight in fixing solution (10\% methanol, $7 \%$ acetic acid; v/v). Proteins were stained with the SYPRO-Ruby fluorescent dye (Molecular Probes) according to manufacturer's instructions, and visualised under UV illumination at $365 \mathrm{~nm}$ using the Molecular Imager VersaDoc MP 4000 Imaging System (Bio-Rad). At least three biological replicates were considered for each fungal sample, with three analytical replicates each.

\section{2-DE analysis}

Digital images of the 2-DE gels were analysed using PDQuest 2-DE Analysis Software (Bio-Rad). Protein spots were considered only when their intensity was at least 20 times the background intensity. The similarity index between two gels was calculated as the ratio between the common spots and the total detected spots. The correlation coefficient was calculated by the PDQuest software. The similarity index provides information on the proportion of spots shared by the gels, whereas the correlation coefficient compares only the amount of protein (as evaluated by optical density) of the shared spots, thus providing information on the level of expression in the different gels.

In order to verify if the same protein content was separated on the gels we performed some statistical analyses. First of all, two tests of normality were performed (KolmogorovSmirnov test and Shapiro-Wilk test). As the samples were not normally distributed, the Wilcoxon-Mann-Whitney test was used to compare both the analytical replicates and the biological replicates.

Protein spots were excised from SYPRO Ruby-stained gels for mass spectrometry identification. Proteins were reduced, alkylated and digested with trypsin. Briefly, the spots were washed twice with water and twice with water/acetonitrile (ACN) and finally with ACN. Gel pieces dried in a Speedvac centrifuge and rehydrated in $20 \mathrm{mM} \mathrm{NH} \mathrm{NCO}_{3}$ buffer containing trypsin. Trypsin digestion was run overnight at $37{ }^{\circ} \mathrm{C}$. The resulting peptide mixture was separated by reverse phase-high performance liquid chromatography (HPLC) on a C18 column using a gradient of $0.1 \%$ trifluoroacetic acid (TFA, Solvent A) and $0.085 \%$ TFA in acetonitrile (Solvent B).

Positive-ion MALDI mass spectra were obtained using an Applied Biosystems 4700 Proteomics Analyzer (Applied Biosystems, Foster City, CA, USA) in reflectron mode. MS spectra were acquired over a mass range of $\mathrm{m} / \mathrm{z} 800-4000$. Monoisotopic masses were obtained from centroids of raw, unsmoothed data. The ten strongest peaks, with a signal to noise greater than 50, from each fraction were selected for CID-MS/MS analysis. A fractionto-fraction precursor exclusion of 200 ppm was used. For CIDMS/MS, a Source 1 collision energy of $1 \mathrm{kV}$ was used, with air as the collision gas. The precursor mass window was set to a relative resolution of 50, and the metastable suppressor was enabled. The default calibration was used for MS/MS spectra, which were baseline-subtracted (peak width 50) and smoothed (Savitsky-Golay with three points across a peak and polynomial order 4); peak detection used a minimum $\mathrm{S} / \mathrm{N}$ of 5 , local noise window of $50 \mathrm{~m} / \mathrm{z}$, and minimum peak width of 2.9 bins. Mass spectral data obtained in batch mode were submitted to database searching using TS2Mascot (Matrix Science, version 1.0.0). A locally-running copy of the Mascot program (Matrix Science Ltd, version 2.1) was used to perform the searches. The peptide fragmentation fingerprinting data were used to search in the NCBI database (NCBInr) with MASCOT software (http://www.matrixscience.com), allowing one missed cleavage of trypsin per peptide, mass tolerance was set at $200 \mathrm{ppm}$ for peptide precursors and at $0.1 \mathrm{Da}$ for fragment ions. The following modifications were permitted (mass change shown in Daltons): carboxyamidomethylated cysteine $(+57)$, oxidized methionine $(+16)$, and ubiquitinated lysine $(+114)$. A minimum confidence of $95 \%(p<0.05)$ and at least 2 peptides were used for 
protein identification. The denovo was run using the DeNovo programme within GPS version 3.6 (Applied Biosystems, Foster City, CA, USA).

\section{Shotgun proteomics}

Four replicates for each treatment, that included two biological replicates with two analytical replicates each, were processed. Proteins were extracted as previously described. Each sample was precipitated with ice-cold acetone overnight at $-80{ }^{\circ} \mathrm{C}$ before being resuspended in $1 \mathrm{~mL}$ of $500 \mathrm{mM}$ TEAB pH 8.0. Each sample was aliquoted in fractions of $0.1 \mathrm{~mL}$, and then proteins were reduced (50 mM TCEP), alkylated (200 mM MMST) and digested (trypsin). Each sample was vacuum dried and resuspended in 10 $\mathrm{mL}$ of $0.1 \%$ TFA for the Applied Biosystems QSTAR (ES-Qq-TOF) analysis. Aliquots of trypsin digests $(3 \mu \mathrm{L})$ were loaded onto an Ultimate nano-HPLC system (Dionex) equipped with a PepMap C18 trap $(300 \mu \mathrm{m} \times 0.5 \mathrm{~cm}$, Dionex $)$ and an Onyx monolithic capillary column $(100 \mu \mathrm{m} \times 15 \mathrm{~cm}$, Phenomenex). The HPLC was interfaced with a QSTAR ${ }^{\circledR}$ API Pulsar i Hybrid LC/MS/MS System (Applied Biosystems) with a MicroIonSpray source (fitted with $20 \mu \mathrm{m}$ ID capillary). Positive ESI MS and MS/MS spectra were acquired over the range $350-1800 \mathrm{~m} / \mathrm{z}$ using information dependent acquisition (IDA). Instrument control, data acquisition and analysis were carried out with Analyst QS v1.1 software. Peptide MS and MS/MS data for database searching were submitted to Mascot (v2.2, Matrix Science), using the NCBInr database. The query data were generated from IDA files using either Mascot script (v1.6b23) or Mascot Daemon (v2.2). The following modifications were permitted (mass change shown in Daltons): carboxyamidomethylated cysteine $(+57)$, oxidized methionine $(+16)$, with MS/MS tolerance $\pm 0.1 \mathrm{Da}$. A minimum confidence of $95 \%$ $(P<0.05)$ was used for peptide identification as defined by the GPS software. Trypsin was specified as the proteolytic enzyme and one miss cleavage was allowed. Mass tolerance was set at $200 \mathrm{ppm}$ for peptide precursors and at 0.1 Da for fragment ions.

The shotgun data were analyzed using KAAS (KEGG Automatic Annotation Server) to assign proteins to functional groups through searches in the KEGG (Kyoto Encyclopedia of Genes and Genomes) database. ${ }^{83}$ One-sided Fisher's exact test $P$ values were calculated to determine whether a particular pathway or Gene Ontology (GO) term was statistically significantly enriched in the proteome identified for the different treatments. ${ }^{84}$

\section{Phylogenetic analysis}

Protein sequences of enzymes of the ureohydrolase superfamily agmatinase, arginase, guanidinobutyrase and proclavaminate amidinohydrolase - were downloaded as protein fasta files from NCBI (http:/www.ncbi.nlm.nih.gov/). Fungal sequences representative of the major phyla (zygomycetes, ascomycetes and basidiomycetes) were used in the alignment, together with agmatinases from vertebrates. Multiple protein alignment was constructed in MUSCLE. ${ }^{85}$ Phylogenetic trees were constructed using the Maximum Likelihood method, using the MEGA software Version $6.0 ;{ }^{86}$ bootstrap analyses were conducted on the basis of 1000 re-samplings of the sequence alignment.

\section{Acknowledgements}

We thank Jerry Thomas, Adam Dowle and David Ashford (University of York, UK) for assistance in mass spectrometry and shotgun proteomics analyses. The sequence data from the $O$. maius $\mathrm{Zn}$ genome were produced by the US Department of Energy Joint Genome Institute http://www.jgi.doe.gov/ in collaboration with the user community. Research was partly funded by the University of Torino.

\section{Notes and references}

1 S. Clemens, Biochimie, 2006, 88, 1707-1719.

2 T. K. S. Janssens, D. Roelofs and N. M. van Straalen, Insect Sci., 2009, 16, 3-18.

3 S. Preveral, L. Gayet, C. Moldes, J. Hoffmann, S. Mounicou, A. Gruet, F. Reynaud, R. Lobinski, J. M. Verbavatz, A. Vavasseur and C. Forestier, J. Biol. Chem., 2009, 284, 4936-4943.

4 H. Frérot, M.-P. Faucon, G. Willems, C. Godé, A. Courseaux, A. Darracq, N. Verbruggen and P. Saumitou-Laprade, New Phytol., 2010, 187, 355-367.

5 J. V. Colpaert, J. H. L. Wevers, E. Krznaric and K. Adriaensen, Ann. Forest Sci., 2011, 68, 17-24.

6 S. E. Smith and D. J. Read, Mycorrhizal Symbiosis, Academic Press, London, 3rd edn, 2008, pp. 145-148, ISBN-10: 123705266.

7 C. Leyval, K. Turnau and K. Haselwandter, Mycorrhiza, 1997, 7, 139-153.

8 N. Corradi and C. Charest, Mol. Ecol., 2011, 20, 3289-3290.

9 J. M. Sharples, A. A. Meharg, S. M. Chambers and J. W. G. Cairney, Nature, 2000, 404, 951-952.

10 J. M. Sharples, A. A. Meharg, S. M. Chambers and J. W. Cairney, Plant Physiol., 2000, 124, 1327-1334.

11 J. V. Colpaert, L. A. Muller, M. Lambaerts, K. Adriaensen and J. Vangronsveld, New Phytol., 2004, 162, 549-559.

12 E. Krznaric, J. H. L. Wevers, C. Cloquet, J. Vangronsveld, F. Vanhaecke and J. V. Colpaert, Environ. Microbiol., 2010, 12, 2133-2141.

13 M. Vallino, E. Zampieri, C. Murat, M. Girlanda, S. Picarella, M. Pitet, E. Portis, E. Martino and S. Perotto, FEMS Microbiol. Ecol., 2011, 75, 321-331.

14 J. Ruytinx, H. Nguyen, M. Van Hees, M. Op De Beeck, J. Vangronsveld, R. Carleer, J. V. Colpaert and K. Adriaensen, Metallomics, 2013, 5, 1225.

15 R. Wysocki and M. J. Tamás, FEMS Microbiol. Rev., 2010, 34, 925-951.

16 M. Bellion, M. Courbot, C. Jacob, D. Blaudez and M. Chalot, FEMS Microbiol. Lett., 2006, 254, 173-181.

17 M. Bellion, M. Courbot, C. Jacob, F. Guinet, D. Blaudez and M. Chalot, New Phytol., 2007, 174, 151-158.

18 H. R. Khouja, S. Abbà, L. Lacercat-Didier, S. Daghino, D. Doillon, P. Richaud, E. Martino, M. Vallino, S. Perotto, M. Chalot and D. Blaudez, Fungal Genet. Biol., 2013, 52, 53-64.

19 D. Blaudez and M. Chalot, Fungal Genet. Biol., 2011, 48, 496-503.

20 W. Bae and X. Chen, Mol. Cell. Proteomics, 2004, 3, 596-607. 
21 M. Thorsen, G. Lagniel, E. Kristiansson, C. Junot, O. Nerman, J. Labarre and M. J. Tamás, Physiol. Genomics, 2007, 30, 35-43.

22 S. Doyle, FEMS Microbiol. Lett., 2011, 321, 1-9.

23 K. Kavanagh, Fungi: Biology and Applications, John Wiley \& Sons, Ltd, Chichester, UK, 2011.

24 S. Ozcan, V. Yildirim, L. Kaya, D. Albrecht, D. Becher, M. Hecker and G. Ozcengiz, Proteomics, 2007, 7, 1249-1260.

25 S. Cherrad, V. Girard, C. Dieryckx, I. R. Gonçalves, J.-W. Dupuy, M. Bonneu, C. Rascle, C. Job, D. Job, S. Vacher and N. Poussereau, Metallomics, 2012, 4, 835.

26 V. García-Cañas, C. Simó, C. León and A. Cifuentes, J. Pharm. Biomed. Anal., 2010, 51, 290-304.

27 F. Schmidt, S. Donahoe, K. Hagens, J. Mattow, U. E. Schaible, S. H. E. Kaufmann, R. Aebersold and P. R. Jungblut, Mol. Cell. Proteomics, 2004, 3, 24-42.

28 C. Abdallah, E. Dumas-Gaudot, J. Renaut and K. Sergeant, Int. J. Plant Genomics, 2012, 2012, 494572.

29 D. P. Gómez-Mendoza, M. Junqueira, L. H. F. do Vale, G. B. Domont, E. X. Ferreira Filho, M. V. de Sousa and C. A. O. Ricart, J. Proteome Res., 2014, 13, 1810-1822.

30 E. Martino, C. Murat, M. Vallino, A. Bena, S. Perotto and P. Spanu, Curr. Genet., 2007, 52, 65-75.

31 S. Abbà, H. R. Khouja, E. Martino, D. B. Archer and S. Perotto, Mol. Plant-Microbe Interact., 2009, 22, 1412-1421.

32 A. Kohler, A. Kuo, L. G. Nagy, E. Morin, K. W. Barry, F. Buscot, B. Canbäck, C. Choi, N. Cichocki, A. Clum, J. Colpaert, A. Copeland, M. D. Costa, J. Doré, D. Floudas, G. Gay, M. Girlanda, B. Henrissat, S. Herrmann, J. Hess, N. Högberg, T. Johansson, H. R. Khouja, K. LaButti, U. Lahrmann, A. Levasseur, E. A. Lindquist, A. Lipzen, R. Marmeisse, E. Martino, C. Murat, C. Y. Ngan, U. Nehls, J. M. Plett, A. Pringle, R. A. Ohm, S. Perotto, M. Peter, R. Riley, F. Rineau, J. Ruytinx, A. Salamov, F. Shah, H. Sun, M. Tarkka, A. Tritt, C. Veneault-Fourrey, A. Zuccaro, Mycorrhizal Genomics Initiative Consortium, A. Tunlid, I. V. Grigoriev, D. S. Hibbett and F. Martin, Nat. Genet., 2015.

33 P. Arora, H. Yamagiwa, A. Srivastava, M. Bolander and U. Sarkar, J. Orthop. Sci., 2005, 10, 160-166.

34 E. Martino, K. Turnau, M. Girlanda, P. Bonfante and S. Perotto, Mycol. Res., 2000, 104, 338-344.

35 M. Chiapello, S. Daghino, E. Martino and S. Perotto, J. Proteome Res., 2010, 9, 3923-3931.

36 S. K. Sharma, P. Goloubinoff and P. Christen, Biochem. Biophys. Res. Commun., 2008, 372, 341-345.

37 M. D. Leach, E. Klipp, L. E. Cowen and A. J. P. Brown, Nature, 2012, 10, 693-704.

38 J. Xu, C. Xue, D. Xue, J. Zhao, J. Gai, N. Guo and H. Xing, PLoS One, 2013, 8, e69810.

39 D. A. Taylor, E. L. Thompson, S. V. Nair and D. A. Raftos, Environ. Pollut., 2013, 178, 65-71.

40 R. Sawarkar, N. Roy, S. Rao, S. Raman, S. Venketesh, K. Suguna and U. Tatu, J. Mol. Biol., 2008, 383, 24-35.

41 S. Koyasu, E. Nishida, T. Kadowaki, F. Matsuzaki, K. Iida, F. Harada, M. Kasuga, H. Sakai and I. Yahara, Proc. Nat. Acad. Sci. U. S. A., 1986, 83, 8054-8058.
42 M. J. Czar, M. J. Welsh and W. B. Pratt, Eur. J. Cell Biol., 1996, 70, 322-330.

43 M. Gorfer, H. Persak, H. Berger, S. Brynda, D. Bandian and J. Strauss, Mycol. Res., 2009, 113, 1377-1388.

44 D. Hosiner, S. Gerber, H. Lichtenberg-Fraté, W. Glaser, C. Schüller and E. Klipp, PLoS One, 2014, 9, e83330.

45 A. Schützendübel and A. Polle, J. Exp. Bot., 2002, 53, 1351-1365.

46 M. Vallino, E. Martino, F. Boella, C. Murat, M. Chiapello and S. Perotto, FEMS Microbiol. Lett., 2009, 293, 48-57.

47 J. L. Hall, J. Exp. Bot., 2002, 53, 1-11.

48 L. A. H. Muller, A. R. Craciun, J. Ruytinx, M. Lambaerts, N. Verbruggen, J. Vangronsveld and J. V. Colpaert, Mycorrhiza, 2007, 17, 571-580.

49 S. Ferreira, K. Hjernø, M. Larsen, G. Wingsle, P. Larsen, S. Fey, P. Roepstorff and M. Salomé Pais, Ann. Bot., 2006, 98, 361-377.

50 C. A. Hamilton, A. G. Good and G. J. Taylor, Plant Physiol., 2001, 125, 2068-2077.

51 P. Kieffer, S. Planchon, M. Oufir, J. Ziebel, J. Dommes, L. Hoffmann, J.-F. Hausman and J. Renaut, J. Proteome Res., 2008, 8, 400-417.

52 M. Dudkowska, J. Lai, G. Gardini, A. Stachurska, B. Grzelakowska-Sztabert, S. Colombatto and M. ManteuffelCymborowska, Biochim. Biophys. Acta, Gen. Subj., 2003, 1619, 159-166.

53 I. V. Grigoriev, R. Nikitin, S. Haridas, A. Kuo, R. Ohm, R. Otillar, R. Riley, A. Salamov, X. Zhao, F. Korzeniewski, T. Smirnova, H. Nordberg, I. Dubchak and I. Shabalov, Nucleic Acids Res., 2013, 42, D699-D704.

54 K. Igarashi and K. Kashiwagi, Biochem. Biophys. Res. Commun., 2000, 271, 559-564.

55 T. Kusano, T. Berberich, C. Tateda and Y. Takahashi, Planta, 2008, 228, 367-381.

56 R. Alcázar, F. Marco, J. C. Cuevas, M. Patron, A. Ferrando, P. Carrasco, A. F. Tiburcio and T. Altabella, Biotechnol. Lett., 2006, 28, 1867-1876.

57 R. Alcázar, T. Altabella, F. Marco, C. Bortolotti, M. Reymond, C. Koncz, P. Carrasco and A. F. Tiburcio, Planta, 2010, 231, 1237-1249.

58 M. D. Groppa and M. P. Benavides, Amino Acids, 2007, 34, 35-45.

59 S. S. Hussain, M. Ali, M. Ahmad and K. H. M. Siddique, Biotechnol. Adv., 2011, 29, 300-311.

60 R. Minocha, R. Majumdar and S. C. Minocha, Front. Plant Sci., 2014, 5, 1-17.

61 X. M. Pang, Z. Y. Zhang, X. P. Wen, Y. Ban and T. Moriguchi, Plant Stress, 2007, 1, 173-188.

62 R. H. Davis, Polyamines in Fungi, 1996.

63 L. Valdés-Santiago, D. Guzmán-de-Peña and J. Ruiz-Herrera, FEMS Yeast Res., 2010, 10, 928-940.

64 L. Valdés-Santiago and J. Ruiz-Herrera, Front. Chem., 2014, 1, 1-10.

65 J. Zarb and D. R. Walters, Mycol. Res., 1996, 100, 486-488.

66 J. Zarb and D. R. Walters, Lett. Appl. Microbiol., 1995, 21, 93-95. 
67 J. P. Wei, C. Srinivasan, H. Han, J. S. Valentine and E. B. Gralla, J. Biol. Chem., 2001, 276, 44798-44803.

68 A. Gárriz, M. E. Gonzalez, M. Marina, O. A. Ruiz and F. L. Pieckenstain, Mycol. Res., 2008, 112, 414-422.

69 L. Valdes-Santiago, J. A. Cervantes-Chavez, R. Winkler, C. G. Leon-Ramirez and J. Ruiz-Herrera, Microbiology, 2012, 158, 674-684.

70 L. Valdés-Santiago, J. A. Cervantes-Chávez, C. G. León-Ramírez and J. Ruiz-Herrera, J. Amino Acids, 2012, 2012, 1-13.

71 N. Beckmann, L. Schafferer, M. Schrettl, U. Binder, H. Talasz, H. Lindner and H. Haas, PLoS One, 2013, 8, e67426.

72 R. D. Klein, T. G. Geary, A. S. Gibson, M. A. Favreau, C. A. Winterrowd, S. J. Upton, J. S. Keithly, G. Zhu, R. L. Malmberg, M. P. Martinez and N. Yarlett, Microbiology, 1999, 145, 301-307.

73 M. Sastre, S. Regunathan, E. Galea and D. J. Reis, J. Neurochem., 1996, 67, 1761-1765.

74 C. W. Tabor and H. Tabor, Microbiol. Rev., 1985, 49, 81-99.

75 A. J. Khan and S. C. Minocha, Life Sci., 1989, 44, 1215-1222.

76 S. Fornalè, T. Sarjala and N. Bagni, New Phytol., 1999, 143, 581-587.
77 A. I. Sannazzaro, C. L. Álvarez, A. B. Menéndez, F. L. Pieckenstain, E. O. Albertó and O. A. Ruiz, FEMS Microbiol. Lett., 2004, 230, 115-121.

78 S. Biondi, M. Mengoli, D. Mott and N. Bagni, Plant Physiol. Biochem., 1993, 31, 51-58.

79 M. Weerasooriya, H. Handagiripathira and G. T. Wijewickrama, J. Sci. Univ. Kelaniya, 2003, 1, 23-34.

80 A. Boldt, J. Miersch and H. Reinbothe, Phytochemistry, 1971, 10, 731-738.

81 G. Bestel-Corre, E. Dumas-Gaudot, V. Poinsot, M. Dieu, J.-F. Dierick, D. van Tuinen, J. Remacle, V. Gianinazzi-Pearson and S. Gianinazzi, Electrophoresis, 2001, 23, 122-137.

82 M. M. M. Bradford, Anal. Biochem., 1976, 72, 248-254.

83 Y. Moriya, M. Itoh, S. Okuda, A. C. Yoshizawa and M. Kanehisa, Nucleic Acids Res., 2007, 35, W182-W185.

84 B. Zhang, N. C. VerBerkmoes, M. A. Langston, E. Uberbacher, R. L. Hettich and N. F. Samatova, J. Proteome Res., 2006, 5, 2909-2918.

85 R. C. Edgar, Nucleic Acids Res., 2004, 32, 1792-1797.

86 K. Tamura, G. Stecher, D. Peterson, A. Filipski and S. Kumar, Mol. Biol. Evol., 2013, 30, 2725-2729. 